\author{
Małgorzata Durbajło-Mrowiec \\ ORCID: 0000-0003-0977-0960 \\ Uniwersytet Wrocławski
}

https://doi.org/10.19195/1733-5779.32.9

\title{
Zróżnicowanie kontroli efektywności form finansowania sportu przez gminę
}

JEL Classification: H83, M19

Słowa kluczowe: kontrola zarządcza, finanse publiczne, zarządzanie, efektywność gmin

Keywords: management control, public finances, management, community efficiency

Abstrakt: Gminy dobrowolnie realizują głównie dwa zadania — z zakresu sportu i rekreacji oraz kultury. W większości działają kluby sportowe, w tym kluby ludowe na wsiach. Wydatki na kulturę fizyczną stanowią kilka procent wydatków budżetowanych. Celem artykułu jest udzielenie odpowiedzi na pytanie, czy mimo stosunkowo małych wydatków na sport, w relacji do innych tytułów, gminy kontrolują efektywność wydatkowanych środków na to dobrowolne zadanie. W tym celu przeprowadzono analizę aktów prawnych, regulujących możliwe formy wydatkowania środków na sport w gminach. Autorka wykorzystała również wiedzę pozyskaną w ramach współpracy z gminami. Zastosowano głównie dwie metody badawcze: badania dokumentów źródłowych i obserwację. Przeprowadzone badania upoważniają do sformułowania wniosku — gminy nie oceniają efektywności wydatków na sport. Takie postępowanie jest sprzeczne z zasadami wydatkowania środków publicznych. Każdy wydatek powinien być celowy, oszczędny i efektywny. Zaproponowane przez autorkę mechanizmy oceny efektywności wydatków są adekwatne do przyjmowanych w gminach rozwiązań organizacyjnych realizacji zadań w zakresie sportu i tym samym form ich finansowania. Dla zapewnienia skuteczności zaproponowanych mechanizmów, należy je włączyć w system kontroli zarządczej gminy.

\section{Differentiation in the control of the effectiveness of forms of financing sport by the community}

Abstract: Municipalities voluntarily carry out two main tasks: in the field of sport and recreation and culture. In most communities there are sports clubs, including folk clubs in villages. Community expenditure on physical culture accounts for several percent of the budgeted expenditure. The purpose of the article is to answer the question as to whether, despite relatively small expenditure on sport, in relation to other titles, municipalities control the effectiveness of funds spent on this voluntary task. To this end, an analysis of legal acts regulating the possible forms of 
spending funds on sport in municipalities was conducted. The author also used the knowledge acquired in cooperation with municipalities. Mainly two research methods were used: research of source documents and observation. The study arrives at the following conclusion: municipalities do not assess the efficiency of spending on sport. Such conduct is contrary to the principles of spending public funds. Each expenditure should be purposeful, economical, and effective. The mechanisms of expenditure efficiency assessment proposed by the author are adequate to the organizational solutions adopted in communities for the implementation of tasks in the field of sport and thus forms of financing them. To ensure the effectiveness of the proposed mechanisms, they should be included in the management control system of the community.

\section{Wprowadzenie}

Gminy dobrowolnie realizują głównie dwa zadania: z zakresu sportu i rekreacji oraz kultury. W większości gmin działają kluby sportowe, w tym kluby ludowe na wsiach. Wydatki gmin na kulturę fizyczną stanowią kilka procent wydatków budżetowanych. Za 2018 rok wydatki gmin w Polsce na ten cel stanowiły 2,6\% łącznych wydatków gmin ${ }^{1}$, w województwie dolnośląskim - 3,7 \% $\%^{2}$. Należy pamiętać, że gminy ponoszą około $50-60 \%{ }^{3}$ wydatków na oświatę i wychowanie oraz rodzinę i pomoc społeczną. W granicach po 7-8\% na łączność i transport, gospodarkę komunalną i ochronę środowiska oraz na utrzymanie i funkcjonowanie administracji publicznej. W 2018 roku gminy, w skali kraju, wydały 3287224 złotych na kulturę fizyczną — o 27,5\% więcej niż w roku poprzednim.

Celem artykułu jest udzielenie odpowiedzi na pytanie: czy mimo stosunkowo niskich wydatków na sport, w relacji do innych tytułów, gminy kontrolują efektywność wydatkowanych środków na to dobrowolne zadanie. W tym celu przeprowadzono analizę aktów prawnych, regulujących możliwe formy wydatkowania środków na sport w gminach. Wykorzystano także wiedzę pozyskaną w ramach współpracy z gminami.

Zastosowano głównie dwie metody badawcze: badania dokumentów źródłowych i obserwację.

\section{Zadania własne gminy w zakresie sportu}

Do zadań gminy należą wszystkie sprawy publiczne o znaczeniu lokalnym dla mieszkańców gminy. Wyjątkiem są sprawy zastrzeżone ustawami na rzecz innych podmiotów. Gmina wykonuje więc zadania w celu zaspokajania potrzeb lokalnej

1 Sprawozdanie z wykonania budżetu państwa za okres od 1 stycznia do 31 grudnia 2018 roku. Informacja o wykonaniu budżetów jednostek samorzadu terytorialnego, Rada Ministrów, Warszawa 2019, s. 65, www.gov.pl/web/finanse/sprawozdanie-roczne-za-2018 (dostęp: 10.03.2020).

2 Wykonanie budżetów jednostek samorzadu terytorialnego województwa dolnośląkiego za 2018 rok, Regionalna Izba Obrachunkowa we Wrocławiu, s. 11, https://bip.wroclaw.rio.gov.pl/dzialalnosc-informacyjna-i-analizy/budzety-jst-opracowania-roczne/4531-wykonanie-budzetow-jst-w-2018-r. (dostęp: 10.03.2020).

${ }^{3}$ Sprawozdanie z wykonania budżetu państwa... 
społeczności, potrzeb zbiorowych oraz dba o rozwój gminy. W art. 7 ustawy o samorządzie gminnym ${ }^{4}$ wymieniono obszerne spektrum zadań własnych gminy, między innymi sprawy:

— ładu przestrzennego, gospodarki nieruchomościami, ochrony środowiska i przyrody oraz gospodarki wodnej;

- gminnych dróg i zbiorowego transportu lokalnego,

- zaopatrzenia w wodę, energię elektryczną i cieplną oraz gaz;

- oczyszczania, utrzymania zieleni i zadrzewień;

— ochrony zdrowia, pomocy społecznej i wspierania rodziny;

- edukacji publicznej;

— kultury, ochrony zabytków, kultury fizycznej i turystyki;

— porządku publicznego i bezpieczeństwa obywateli;

- utrzymania gminnych obiektów i urządzeń użyteczności publicznej oraz obiektów administracyjnych.

Wymieniony zakres zadań nie jest katalogiem zamkniętym. Część z wymienionych zadań to zadania obowiązkowe, część ma charakter dobrowolny. Gmina wykonuje swoje zadania publiczne w imieniu własnym i na własną odpowiedzialność. Finansuje realizację tych zadań z własnych środków. Zadania w zakresie sportu są ujęte w dwóch grupach spraw, a mianowicie: towych,

— kultury fizycznej i turystyki, w tym terenów rekreacyjnych i urządzeń spor-

— utrzymania gminnych obiektów i urządzeń użyteczności publicznej.

W art. 2. ustawy o sporcie ${ }^{5}$ zdefiniowano pojęcie kultury fizycznej i sportu. Według ustawodawcy na kulturę fizyczną składają się sport, wychowanie fizyczne i rehabilitacja ruchowa. Pod pojęciem zaś sportu należy rozumieć wszelkie formy aktywności fizycznej i intelektualnej, których celem jest osiąganie wyników sportowych, budowa lub poprawa kondycji fizycznej i psychicznej, rozwój stosunków społecznych bez względu na to, czy aktywność ta ma charakter doraźny, czy zorganizowany. W rozporządzeniu Ministra Finansów w sprawie szczegółowej klasyfikacji dochodów, wydatków, przychodów i rozchodów oraz środków pochodzących ze źródeł zagranicznych ${ }^{6}$ w dziale 926 - Kultura fizyczna wskazano, że w dziale tym należy ujmować dochody i wydatki publiczne, przychody i inne środki z zakresu działalności związanej ze sportem oraz działalności rekreacyjnej i rozrywkowej. Klasyfikacja budżetowa nie jest więc zgodna z definicjami prezentowanymi w ustawie szczegółowej. W obydwu jednak przypadkach sport jest immanentną składową kultury fizycznej.

${ }^{4}$ Ustawa z dnia 8 marca 1990 roku o samorządzie gminnym (tekst jedn. Dz.U. z 2019 r. poz. 506).

5 Ustawa z dnia 25 czerwca 2010 roku o sporcie (tekst jedn. Dz.U. z 2019 r. poz. 1468).

${ }^{6}$ Rozporządzenie Ministra Finansów z dnia 2 marca 2010 roku w sprawie szczegółowej klasyfikacji dochodów, wydatków, przychodów i rozchodów oraz środków pochodzących ze źródeł zagranicznych (tekst jedn. Dz.U. z 2014 r. poz. 1053). 
W art. 27 ustawy o sporcie wskazano możliwość dofinansowania przez jednostki samorządu tery torialnego działań, których celem jest tworzenie warunków, w tym organizacyjnych, sprzyjających rozwojowi sportu. Jednostki samorządowe nie muszą obejmować wsparciem wszelkiej aktywności sportowej i wspieranie to nie może być bezwarunkowe ${ }^{7}$. Jednostki samorządu terytorialnego mogą wybrać różne dyscypliny, o znaczeniu lokalnym, i różne ich formy ${ }^{8}$. Do zadań gminy w zakresie sportu należy więc z pewnością organizowanie sportu na terenie gminy, stwarzane warunków materialno-technicznych odnośnie do aktywności fizycznej i intelektualnej mieszkańców, którzy chcą uprawiać sport, oraz podejmowanie działań na rzecz rozwoju i promowania sporu w gminie. W tym zakresie gmina (urząd miasta/gminy, gminne jednostki organizacyjne) może organizować zawody sportowe, tworzyć i finansować kluby sportowe, prowadzić wypożyczalnie sprzętu sportowego i turystycznego, organizować nauki pływania, organizować zajęcia i imprezy sportowo-rekreacyjne, zapewniać odpowiednią kadrę instruktorską, budować i utrzymywać obiekty sportowe.

\section{Formy finansowania sportu w gminie}

Przeprowadzone badania podstaw prawnych finansowania sportu - ustawy o finansach publicznych, ustawy o sporcie, ustawy o działalności pożytku publicznego i wolontariacie ${ }^{9}$, ustawy o gospodarce komunalnej ${ }^{10}$ — upoważniają do stwierdzenia, że ustawodawca uzależnił finansowanie zadań w zakresie sportu od przyjętego sposobu realizacji zadań publicznych w gminie i podjętych przez organy jednostek samorządu terytorialnego decyzji o formułach wykonywania tych zadań. Zadania gminy w zakresie sportu mogą być realizowane przez:

- komórki organizacyjne urzędu gminnego (wydział, referat);

— komunalne zakłady budżetowe, na przykład popularne ośrodki rekreacji i sportu (OSiR);

— podmioty spoza sektora finansów publicznych (stowarzyszenia, fundacje, kluby sportowe);

— komunalne spółki prawa handlowego, najczęściej kluby sportowe, działające w formie spółek z ograniczoną odpowiedzialnością lub spółek akcyjnych.

W ustawie o finansach publicznych przewidziano generalnie dwie możliwości finansowania zadań własnych — bezpośrednio z budżetu gminy, jeśli zadania

7 II GSK 282/18, wyrok NSA (N) z dnia 19 czerwca 2018 roku, https://sip.legalis.pl/document-full.seam?documentId=mrswglrtgy3domzvgq3de) (dostęp: 1.02.2020).

${ }^{8}$ III SA/Gd 1126/16, wyrok WSA Gdańsk z dnia 23 lutego 2017 roku, https://sip.legalis.pl/ document-full.seam?documentId=mrswglrtgy3dkmzrgi2dm (dostęp: 1.02.2020).

9 Ustawa z dnia 24 kwietnia 2003 roku o działalności pożytku publicznego i o wolontariacie (tekst jedn. Dz.U. z 2019 r. poz. 688).

${ }^{10}$ Ustawa z dnia 20 grudnia 1996 roku o gospodarce komunalnej (tekst jedn. Dz.U. z 2019 r. poz. 712). 
realizuje komórka urzędu miejskiego/gminnego/miejsko-gminnego lub poprzez udzielenie dotacji z budżetu jednostki samorządu terytorialnego.

W przedmiotowym zakresie gmina może udzielić dotacji przedmiotowych i celowych. Zgodnie z art. 126 ustawy o finansach publicznych dotacje to wydatki o charakterze nieodpłatnym i bezzwrotnym, podlegające szczególnym zasadom rozliczenia. Są udzielane na podstawie ustawy o finansach publicznych lub odrębnych ustaw. Zawsze są przeznaczone na finansowanie lub dofinansowanie realizacji zadań publicznych.

Realizując zadania z zakresu sportu, gmina może również zakładać spółki prawa handlowego. Taką możliwość daje ustawa o gospodarce komunalnej. W art. 10 tej ustawy stwierdzono, że gmina poza sferą użyteczności publicznej może tworzyć spółki prawa handlowego i przystępować do nich, jeżeli łącznie zostaną spełnione następujące warunki:

— istnieją niezaspokojone potrzeby wspólnoty samorządowej na rynku lokalnym;

— w gminie występuje bezrobocie.

Z powyższej regulacji wynika również prawo gminy do utworzenia spółki prawa handlowego i przystępowania do spółki poza sferą użyteczności publicznej, wówczas jeżeli zagospodarowanie posiadanego majątku, na przykład poprzez sprzedaż, spowoduje znaczącą stratę majątkową, jeśli majątek nie zostanie wniesiony do spółki. Wskazane ograniczenia, dotyczące tworzenia spółek prawa handlowego i przystępowania do nich przez gminę, nie mają zastosowania między innymi do klubów sportowych, działających w formie spółki kapitałowej.

Gminy mogą również zachęcać podmioty prywatne do prowadzenia działalności w zakresie sportu i rekreacji poprzez system bonifikat przy sprzedaży nieruchomości, obniżania podatków pobieranych przez gminę ${ }^{11}$.

Podsumowując, należy stwierdzić, że gmina może przyjąć następujące rozwiązania organizacyjne realizacji zadań własnych gminy w zakresie sportu i tym samym określić formy ich finansowania, a mianowicie:

- zadania realizuje komórka organizacyjna gminy, na przykład wydział, referat, i wówczas wydatki na sport są wydatkami bieżącymi urzędu gminnego, ewentualnie wydatkami majątkowymi;

— zadania realizuje gminny zakład budżetowy, który otrzymuje dotacje przedmiotowe $\mathrm{z}$ budżetu gminy ${ }^{12}$ na sfinansowanie kosztów utrzymania i eksploatacji obiektów sportowych, na przykład stadionu, hali sportowej, basenu, oraz na sfinansowanie kosztów organizacji imprez sportowych i rekreacyjno-sportowych.

11 L. Borowiec, Controlling w realizacji usług publicznych gminy, Warszawa 2007.

12 Samorządowy zakład budżetowy może również otrzymać dotację celową ( $\$ 38$ ust. 1 rozporządzenia Ministra Finansów z dnia 7 grudnia 2010 roku w sprawie sposobu prowadzenia gospodarki finansowej jednostek budżetowych i samorządowych zakładów budżetowych; tekst jedn. Dz.U. z 2019 r. poz. 1718). 
Dotacje przedmiotowe są dopłatą do usług deficytowych świadczonych przez zakład, gdy cena za te usługi nie pokrywa kosztów ich świadczenia z przyczyn niezależnych od zakładu budżetowego;

— zadania realizują różne podmioty ze sfery finansów publicznych i spoza niej, i pozyskują w trybie konkursowym dotacje celowe z budżetu gminy na realizację określonych celów, na przykład sfinansowanie lub dofinansowanie organizacji imprez sportowych, zakup środków trwałych na potrzeby realizowanego celu, pokrycie kosztów funkcjonowania klubu sportowego, sfinansowanie stypendiów sportowych;

— zadania realizują spółki prawa handlowego i są dofinansowywane w sposób dopuszczony kodeksem spółek handlowych, czyli poprzez podwyższenie kapitału i dopłaty wspólników.

\section{Dotacje przedmiotowe na sport}

Gmina może udzielać dotacji przedmiotowych dla samorządowych zakładów budżetowych i innych podmiotów, również na podstawie odrębnych ustaw. Z założenia zakład budżetowy ma pokrywać ponoszone koszty z osiąganych przychodów. Jeśli cena usługi komunalnej lub wyrobu nie rekompensuje poniesionych kosztów ich wytworzenia, gmina może (ale nie ma takiego obowiązku) podjąć decyzję o dofinansowaniu zakładu w formie dotacji przedmiotowej. Każda dotacja przedmiotowa jest dopłatą do wyrobu lub usługi, a jej wysokość jest kalkulowana według stawek jednostkowych, na przykład zł $/ \mathrm{m}^{2}$. Kwota dopłaty jest różnicą między ceną sprzedaży usługi/wyrobu a kosztem jednostkowym ich wytworzenia. Dotacja przedmiotowa nie może wyrównywać poziomu przychodów i kosztów zakładu budżetowego ${ }^{13}$. Kwoty i zakres dotacji przedmiotowej muszą być określone w uchwale budżetowej, a stawki dotacji przedmiotowych ustala organ stanowiący jednostki samorządu terytorialnego, czyli rada miejska w gminie (art. 219). Na wysokość stawki wpływa rodzaj prowadzonej działalności przez beneficjenta, jak również przyjęta podstawa kalkulacji stawki. Dotacja przedmiotowa musi być udzielona do konkretnej usługi czy wyrobu-przedmiotu ${ }^{14}$.

Finansowanie sportu w tej formie jest możliwe wówczas, gdy zadania z zakresu sportu będzie realizował gminny zakład budżetowy. Gmina może wówczas dopłacać do metra kwadratowego boiska, hali sportowej, godziny otwarcia lodowiska.

13 I SA/Sz 346/13, https://sip.lex.pl/\#/jurisprudence/521410292/1/i-sa-sz-346-13-dotacja-przedmiotowa-zastosowanie-definicji-dotacji-na-potrzeby-gminy-wyrok...?cm=URELATIONS) (dostęp: 30.01.2020).

14 https://sip.lex.pl/\#/question-and-answer/620925036/czy-samorzadowy-zaklad-budzetowy-moze-otrzymac-dotacje-przedmiotowa-na-pokrycie-kosztow-obiektu...?cm=URELATIONS (dostęp: 30.01.2020). 


\section{Dotacje celowe na sport}

Dotacje celowe to wydatki budżetowe będące pomocą finansową dla innych podmiotów, z przeznaczeniem na sfinansowanie lub dofinansowanie realizacji zadań publicznych, związanych z działalnością danej jednostki samorządu terytorialnego (art. 220 i art. 221 ustawy o finansach publicznych). Dotacje celowe pozwalają finansować zadania publiczne, scedowane do wykonania na beneficjentów dotacji celowej. Są udzielane na sfinansowanie konkretnego wskazanego celu, na przykład zawodów sportowych. Dotacje celowe mogą być udzielane na rzecz bliżej nieokreślonego kręgu podmiotów i przekazywane innym jednostkom samorządu terytorialnego (art. 220 ust. 1 ustawy o finansach publicznych), innym podmiotom, zaliczanym do sektora finansów publicznych, na podstawie odrębnych ustaw (na przykład dla klubów sportowych na zadania z zakresu sportu; art. 28 ust. 1 ustawy o sporcie) oraz podmiotom spoza sektora finansów publicznych (art. 221 ustawy o finansach publicznych). W ostatnim przypadku beneficjentem dotacji celowych nie mogą być podmioty działające $\mathrm{w}$ celu osiągnięcia zysku. Z dotacji celowych dla podmiotów spoza sektora finansów publicznych mogą być pokrywane wydatki na realizację powierzonych zadań, jak też dofinansowanie inwestycji związanych z realizacją tych zadań. Takie zadania są zlecane, a dotacje celowe na ich realizację udzielane na podstawie ustawy o działalności pożytku publicznego i o wolontariacie. Zgodnie ze wskazaną regulacją prawną gminy mają obowiązek współpracy i działalności na rzecz organizacji pozarządowych, między innymi w zakresie kultury fizycznej. Współpraca ta polega na finansowaniu lub współfinansowaniu projektów realizowanych przez organizacje pożytku publicznego.

Podstawą udzielenia dotacji celowej na inne zadania niż określone w ustawie o działalności pożytku publicznego i o wolontariacie może być jedynie uchwała organu stanowiącego gminy czy organu stanowiącego inne jednostki samorządu terytorialnego.

Aby udzielić dotacji celowej, jednostka samorządu terytorialnego jest zobowiązana podpisać umowę regulującą szczegóły dofinansowania.

Zgodnie z art. 221a ustawy o finansach publicznych z budżetu jednostki samorządu terytorialnego mogą być udzielane dotacje celowe na dofinansowanie kosztów inwestycji, związanych z wykonywaniem zadań publicznych jednostki w ramach umów o partnerstwie publiczno-prywatnym. Udzielenie dotacji w tym przypadku następuje na podstawie umowy o partnerstwie publiczno-prywatnym, z uwzględnieniem przepisów o postępowaniu w sprawach dotyczących pomocy publicznej.

Dotacja celowa jest najczęściej stosowaną formą finansowania zadań własnych gminy w zakresie sportu. Corocznie w gminach są ogłaszane konkursy na wykonanie zadań publicznych przez organizacje pozarządowe i inne uprawnione podmioty prowadzące działalność pożytku publicznego, między innymi w ob- 
szarze upowszechniania kultury fizycznej i sportu. Zadanie wspierania sportu w gminach jest realizowane również poprzez udzielanie dotacji celowych na podstawie ustawy o sporcie. W uchwałach rad gminy wskazuje się cel publiczny tych dotacji, na przykład polepszenie warunków uprawiania sportu przez zawodników klubów sportowych; osiągnięcie wysokich wyników sportowych przez zawodników klubów sportowych; poprawę kondycji fizycznej i zdrowia psychicznego mieszkańców poprzez uczestnictwo w aktywnym stylu życia; promocję sportu i aktywnego stylu życia; umożliwienie dostępu do różnorodnych form aktywności sportowej jak największej liczbie mieszkańców gminy. Tak sformułowany cel pozwala finansować z tych dotacji stypendia dla zawodników i trenerów, zakupy sprzętu treningowego, opłaty za korzystanie z obiektów sportowych itp.

\section{Ocena efektywności wydatków poniesionych przez gminę na sport}

Kontrola wydatkowanych środków publicznych w gminach odbywa się przez nadzór wykonania budżetu oraz kontrolę i rozliczanie powierzonych zadań publicznych oraz dotacji przekazanych na ich sfinansowanie. Zgodnie z art. 247 ust. 2 ustawy o finansach publicznych ogólny nadzór nad realizacją określonych w uchwale budżetowej dochodów, przychodów, wydatków i rozchodów sprawuje zarząd jednostki samorządu terytorialnego, czyli w gminach — burmistrz/wójt/ prezydent. Zgodnie z art. 254 ustawy o finansach publicznych nadzór ten ma zapewnić dokonywanie wydatków w granicach kwot określonych w planie finansowym i zgodnie z planowanym przeznaczeniem, w sposób celowy i oszczędny, z zachowaniem zasady uzyskiwania najlepszych efektów z danych nakładów. Zlecanie zadań powinno następować na zasadzie wyboru najkorzystniejszej oferty. Ustawa o finansach publicznych nie zawiera szczególnych regulacji dotyczących zasad kontroli ponoszonych wydatków i ich rozliczania. Zasady takie mogą być określone w ustawach szczegółowych, podjętych uchwałach przez organy stanowiące i popisanych umowach dotacyjnych.

Zasady rozliczania przekazanych środków na sport są zróżnicowane w zależności od przyjętej formy organizacyjno-prawnej realizacji tej grupy zadań własnych gminy i rodzaju wydatku/dotacji.

W wypadku dotacji przedmiotowej sposób rozliczenia winien zostać określony przez burmistrza gminy. Taki obowiązek można wywieść z zapisu $§ 45$ ust. 2 rozporządzenia w sprawie sposobu prowadzenia gospodarki finansowej jednostek budżetowych i samorządowych zakładów budżetowych ${ }^{15}$. We wskazanym paragrafie zobowiązano kierownika samorządowego zakładu budżetowego do prze-

15 Rozporządzenie Ministra Finansów z dnia 7 grudnia 2010 roku w sprawie sposobu prowadzenia gospodarki finansowej jednostek budżetowych i samorządowych zakładów budżetowych (tekst jedn. Dz.U. z 2019 r. poz. 1718). 
kazywania burmistrzowi rozliczenia wykorzystania otrzymanej dotacji. Sposób rozliczenia dotacji przedmiotowej, zakres i stopień szczegółowości sprawozdania powinien zostać ustalony w zarządzeniu burmistrza.

Przegląd przedmiotowych zarządzeń wskazuje, że beneficjent dotacji przedmiotowej jest zobowiązany do przedstawienia rozliczenia cząstkowego (miesięcznego) i rocznego, w których wykazuje liczbę jednostek miary wyrobu/usługi, ustaloną przez organ stanowiący stawkę jednostkową dotacji i liczbę miesięcy świadczenia usługi/wytwarzania wyrobu oraz kwotę dotacji niewykorzystanej.

Według autorki najprostsza ocena efektywności wydatkowania środków budżetowych $\mathrm{w}$ formie dotacji przedmiotowych może polegać na porównaniu kosztów jednostkowych świadczonych usług/wytwarzanych wyrobów przez zakład budżetowy z cenami rynkowymi tych usług/wyrobów. Wskazane jednak jest, aby taka ocena następowała na etapie planowania wydatków zakładu i przygotowania budżetu gminy, w którym należy ująć zestawienie dotacji. Podstawą ustalenia stawki dopłaty muszą być informacje finansowe, przekazane przez zakład budżetowy, nie tylko o kosztochłonności usług/wyrobów, które mają być objęte dopłatą. Gmina musi mieć możliwość sprawdzenia, czy przyznane dopłaty nie będą zwiększały wyniku finansowego zakładu. Informacje zawarte w planie finansowym zakładu budżetowego, w którym wykazuje się wpływy i wydatki całkowite według klasyfikacji budżetowej, nie są wystarczające do oceny efektywności udzielanych dotacji przedmiotowych. Analiza efektywności dotacji na etapie planowania, a nie dopiero po wykonaniu, rzeczywiście spełni swój cel.

W wypadku dotacji celowych na sport zasady rozliczania są określone w ustawach szczegółowych, na podstawie których podmioty realizujące zadania w zakresie sportu mogą otrzymać dotacje celowe, a mianowicie w ustawie o sporcie oraz ustawie o działalności pożytku publicznego i wolontariacie.

W ustawie o sporcie określono cele, na które może zostać przeznaczona dotacja, i umocowano organ stanowiący jednostki samorządu tery torialnego do określenia warunków i trybu finansowania zadania własnego w formie uchwały. Zgodnie z wyrokiem Naczelnego Sądu Administracyjnego z dnia 26 kwietnia 2016 roku $^{16}$ uchwała powinna określać:

— rodzaj wydatków, na które może zostać przeznaczona dotacja,

— wszelkie kryteria, jakimi będzie się kierował organ wykonawczy, dokonując oceny ofert,

— obowiązujące w tym postępowaniu terminy,

— warunki zapewnienia jawności postępowania o udzielenie dotacji,

— zasady rozliczenia dotacji.

16 II GSK 2560/14, https://sip.lex.pl/\#/jurisprudence/522159002/1/ii-gsk-2560-14-przekazanieprzez-rade-gminy-organowi-wykonawczemu-skonkretyzowania-uchwaly-w...?cm=URELATIONS (dostęp: 20.01.2020). 
Regionalna Izba Obrachunkowa w Poznaniu w uchwale z dnia 20 kwietnia 2014 roku ${ }^{17}$ wskazała, że rada gminy ma wyłączne kompetencje do określenia warunków i trybu finansowania zadania własnego z zakresu sportu. Według rozstrzygnięcia nadzorczego rada gminy jest zobowiązania w sposób jednoznaczny określić wszystkie elementy trybu ubiegania się o dotacje celowe z ustawy o sporcie, w tym zawartość wniosku i dokumentów dołączanych do wniosku.

Przegląd uchwał rad gmin w tym zakresie wskazuje, że we wniosku i sprawozdaniu z wykonania zadania beneficjent jest zobowiązany określić:

— rodzaj zadania, termin i miejsce jego realizacji oraz szczegółowy zakres zadania wraz z harmonogramem podejmowanych działan, odbiorców zadania, jego cel i rezultaty;

— koszt realizacji zadania z wykazaniem ceny jednostkowej i liczby jednostek miary usługi oraz z podziałem na źródła finansowania: z dotacji i innych źródeł, w tym ze środków własnych;

- wyspecyfikować faktury potwierdzające poniesione wydatki z podaniem numery dowodu i daty jego wystawienia.

Przewidziany $\mathrm{w}$ większości dokumentacji obowiązek podania algorytmu obliczeniowego planowanych i poniesionych kosztów/wydatków pozwala gminie, zdaniem autorki, włączyć do rozliczenia dotacji ocenę efektywności wydatkowanych środków publicznych, na przykład przez porównanie stawek jednostkowych wydatków z wzorcem-kosztorysem oraz z cenami rynkowymi.

W zakresie dotacji celowej, udzielanej na podstawie ustawy o działalności pożytku publicznego i wolontariacie oraz art. 151 ustawy o finansach publicznych, gmina może zlecić organizacji pozarządowej realizację swoich zadań na podstawie umowy zawartej z tą organizacją i przekazać jednocześnie dotację celową na realizację tych zadań. Zasady udzielenia dotacji ma regulować umowa zawarta przez burmistrza gminy. Zgodnie z zapisem art. 151 ust. 2 ustawy o finansach publicznych umowa musi określać:

— szczegółowy opis zadania, w tym cel i termin wykonania zadania;

— wysokość udzielonej dotacji i tryb płatności;

— termin wykorzystania dotacji;

- tryb kontroli wykonywania zadania;

— termin i sposób rozliczenia udzielonej dotacji;

- termin zwrotu niewykorzystanej części dotacji.

We wzorach ofert i sprawozdań z wykonania zadań przez organizacje pozarządowe wprowadzonych rozporządzeniem Przewodniczącego Komitetu do spraw

${ }^{17}$ Uchwała Kolegium Regionalnej Izby Obrachunkowej w Poznaniu z dnia 20 kwietnia 2016 roku, 8/504/2016, https://sip.lex.pl/\#/jurisprudence/538902096/1/8-504-2016-wylacznosc-kompetencji-rady-gminy-do-okreslenia-warunkow-i-trybu-finansowania-zadania...?cm=URELATIONS (dostęp: 20.01.2020). 
Pożytku Publicznego z dnia 24 października 2018 roku $^{18}$, przewidziano ustalanie rezultatów planowanych i zrealizowanych, wraz ze wskazaniem miernika pomiaru rezultatu i jego wskaźnika oraz kosztów realizacji poszczególnych działań, wraz z podaniem rodzaju kosztu, jego poziomu jednostkowego i liczny jednostek miary, na przykład „km”, „szt”. Taki zestaw informacji według autorki pozwala oceniać efektywność planowanej i wydatkowanej dotacji celowej w najbardziej typowy sposób, a mianowicie przez odniesienie rezultatów do poniesionych kosztów, co oznacza na przykład ustalenie kosztu szkolenia jednego zawodnika, kosztu zorganizowania i przeprowadzenia rozgrywek dla jednego uczestnika lub drużyny. Porównanie ustalonych wskaźników w czasie oraz przeprowadzenie benchmarkingu będzie dobrą podstawą do oceny efektywności zrealizowanego celu.

W każdej dotacji celowej pozostaje jeszcze kwestia oceny udziału finansowego gminy w wydatkach poniesionych przez organizację realizującą cel, gdy gmina jest jednym ze współfinansujących projekt. Najczęściej gmina jest jedynym udzielającym dotacje. Niekiedy część wydatków finansowana jest z wkładu własnego beneficjenta. Nie ulega wątpliwości, że udzielona dotacja nie powinna poprawiać sytuacji finansowej beneficjenta podobnie jak dotacje — przedmiotowej. Zgodnie z zasadami udzielania dotacji celowych i ich rozliczania zapisanymi w przedmiotowych regulacjach prawnych nie zapewniono gminie dostępności do informacji finansowych i sprawozdań finansowych beneficjenta. Analiza tych danych pozwoliłaby stwierdzić, czy wpływy i wydatki na dotowany cel nie mają znaczenia dla wyniku finansowego beneficjenta.

Powtarzająca się potrzeba analizy sytuacji finansowej beneficjenta przy kolejnych dotacjach jest jedynym sposobem oceny efektywności wydatków gminy na sport $\mathrm{w}$ formie wkładu na pokrycie udziałów w spółce prawa handlowego oraz dopłat do kapitału spółki. W podmiotach tych dostępność właścicieli do danych finansowych i sprawozdań spółki jest określona w kodeksie spółek handlowym: głównie poprzez przedstawicieli w organie nadzorczym do informacji bieżących, okresowo przed zatwierdzeniem rocznego sprawozdawania finansowego. Dodatkowo, w ramach obowiązkowego nadzoru nad spółkami komunalnymi ${ }^{19}$, burmistrz określa (w formie zarządzenia) zasady sprawowanego nadzoru, w tym obowiązki informacyjne spółek, zwykle obowiązek przekazywania sprawozdań finansowych lub sprawozdań wewnętrznych, ujmujących dane finansowe. Gmina ma więc wystarczający dostęp do danych finansowych spółek komunalnych, aby na bieżąco oceniać efektywność tej formy wydatków na sport.

18 Rozporządzenie Przewodniczącego Komitetu do spraw Pożytku Publicznego z dnia 24 października 2018 roku w sprawie wzorów ofert i ramowych wzorów umów dotyczących realizacji zadań publicznych oraz wzorów sprawozdań z wykonania tych zadań (Dz.U. z 2018 r. poz. 2057).

19 Art. 30 ust. 1 pkt 3 ustawy z dnia 20 grudnia 1996 roku o gospodarce komunalnej (tekst jedn. Dz.U. z 2019 poz. 712). 


\section{Podsumowanie}

Podsumowując, należy stwierdzić, że gminy nie oceniają efektywności wydatków na sport. Taki stan rzeczy nie może wyjaśniać małego zaangażowania procentowego środków finansowych gmin w realizację zadań w zakresie sportu. Każda wydatkowana kwota pochodzi ze środków publicznych i jej wydatkowanie powinno podlegać takim samym zasadom jak przeważające wydatki w budżecie gminy, a więc powinno być celowe, oszczędne i efektywne. Zaproponowane mechanizmy są adekwatne do przyjmowanych $w$ gminach rozwiązań organizacyjnych realizacji zadań w zakresie sportu i tym samym form ich finansowania.

Uprawnienia nadane kierownikom jednostek samorządu terytorialnego art. 68 ustawy o finansach publicznych w zakresie kontroli zarządczej umożliwiają burmistrzom wprowadzenie szczegółowych zasad oceny zrealizowanych wydatków. Zapis ten pozwala - zaproponowane przez autorkę - oceny efektywności wydatków na sport włączyć w system kontroli zarządczej gminy. Każda komórka organizacyjna gminy rozliczająca dotacje, realizująca zadania w zakresie sportu oraz nadzorująca spółki komunalne w ramach celu: utrzymanie/zwiększenie efektywności wydatków, powinna mieć ustalony miernik i jego wskaźnik na dany rok budżetowy.

Argumentem mobilizującym burmistrzów i skarbników gmin do wprowadzenia oceny efektywności ponoszonych wydatków, w tym na sport, jest zapis art. 8 ustawy o odpowiedzialności za naruszenie dyscypliny finansów publicznych ${ }^{20}$. Zgodnie z jego zapisem przekazanie lub udzielenie dotacji z naruszeniem zasad lub trybu przekazywania, lub udzielania dotacji, niezatwierdzenie w terminie przedstawionego rozliczenia dotacji, nieustalenie kwoty dotacji, podlegającej zwrotowi do budżetu, jest naruszeniem dyscypliny finansów publicznych.

\section{Bibliografia}

Borowiec L., Controlling w realizacji ustug publicznych gminy, Warszawa 2007.

Sprawozdanie z wykonania budżetu państwa za okres od 1 stycznia do 31 grudnia 2018 r. Informacja o wykonaniu budżetów jednostek samorządu terytorialnego, Rada Ministrów, Warszawa 2019. Uchwała Kolegium Regionalnej Izby Obrachunkowej w Poznaniu z dnia 20 kwietnia 2016 r.,

8/504/2016, https://sip.lex.pl/\#/jurisprudence/538902096/1/8-504-2016-wylacznosc-kompetencji-rady-gminy-do-okreslenia-warunkow-i-trybu-finansowania-zadania...?cm=URELATIONS Wykonanie budżetów jednostek samorządu terytorialnego województwa dolnośląskiego za 2018 rok,

Regionalna Izba Obrachunkowa we Wrocławiu, https://bip.wroclaw.rio.gov.pl/dzialalnosc-informacyjna-i-analizy/budzety-jst-opracowania-roczne/4531-wykonanie-budzetow-jst-w-2018-r.

20 Ustawa z dnia 17 grudnia 2004 roku o odpowiedzialności za naruszenie dyscypliny finansów publicznych (tekst jedn. Dz.U. z 2019 r. poz. 1440). 


\section{Wykaz aktów prawnych}

Rozporządzenie Ministra Finansów z dnia 2 marca 2010 roku w sprawie szczegółowej klasyfikacji dochodów, wydatków, przychodów i rozchodów oraz środków pochodzących ze źródeł zagranicznych (tekst jedn. Dz.U. z 2014 r. poz. 1053).

Rozporządzenie Ministra Finansów z dnia 7 grudnia 2010 roku w sprawie sposobu prowadzenia gospodarki finansowej jednostek budżetowych i samorządowych zakładów budżetowych (tekst jedn. Dz.U. z 2019 r. poz. 1718).

Rozporządzenie Przewodniczącego Komitetu do spraw Pożytku Publicznego z dnia 24 października 2018 roku w sprawie wzorów ofert i ramowych wzorów umów dotyczących realizacji zadań publicznych oraz wzorów sprawozdań z wykonania tych zadań (Dz.U. z 2018 r. poz. 2057).

Ustawa z dnia 8 marca 1990 roku o samorządzie gminnym (tekst jedn. Dz.U. z 2019 r. poz. 506).

Ustawa z dnia 24 kwietnia 2003 roku o działalności pożytku publicznego i o wolontariacie (tekst jedn. Dz.U. z 2019 r. poz. 688).

Ustawa z dnia 25 czerwca 2010 roku o sporcie (tekst jedn. Dz.U. z 2019 r. poz. 1468).

Ustawa z dnia 17 grudnia 2004 roku o odpowiedzialności za naruszenie dyscypliny finansów publicznych (tekst jedn. Dz.U. z 2019 r. poz. 1440).

Ustawa z dnia 20 grudnia 1996 roku o gospodarce komunalnej (tekst jedn. Dz.U. z 2019 r. poz. 712).

I SA/Sz 346/13, https://sip.lex.pl/\#/jurisprudence/521410292/1/i-sa-sz-346-13-dotacja-przedmiotowa-zastosowanie-definicji-dotacji-na-potrzeby-gminy-wyrok...?cm=URELATIONS).

II GSK 2560/14, https://sip.lex.pl/\#/jurisprudence/522159002/1/ii-gsk-2560-14-przekazanie-przez-rade-gminy-organowi-wykonawczemu-skonkretyzowania-uchwaly-w...?cm=URELATIONS.

II GSK 282/18, wyrok NSA (N) z dnia 19 czerwca 2018 roku, https://sip.legalis.pl/document-full. seam?documentId=mrswglrtgy3domzvgq3de).

III SA/Gd 1126/16, wyrok WSA Gdańsk z dnia 23 lutego 2017 roku, https://sip.legalis.pl/document-full.seam?documentId=mrswglrtgy3 dkmzrgi2 $\mathrm{dm}$.

\section{Strony internetowe}

www.gov.pl/web/finanse/sprawozdanie-roczne-za-2018.

https://sip.lex.pl/\#/question-and-answer/620925036/czy-samorzadowy-zaklad-budzetowy-moze-otrzymac-dotacje-przedmiotowa-na-pokrycie-kosztow-obiektu...?cm=URELATIONS. 